\title{
Hydrogeochemistry of Groundwater from Kazaure Area, NW Nigeria using Multivariate Statistics
}

\author{
Musa Ado ${ }^{1}$, Oluwafemi Adeyeye ${ }^{2}$, Changlai Xiao, ${ }^{2, *}$, and Xuijuan Liang ${ }^{2}$ \\ ${ }^{1}$ Department of Geology, Rabiu Musa College of Advanced Remedial Studies, Kano, Nigeria \\ ${ }^{2}$ College of New Energy and Environment, Jilin U., 2519, Jiefang Road, Changchun 130021, PR \\ China
}

\begin{abstract}
This study was aimed at understanding the factors affecting groundwater for the benefit of water resources management. Groundwater collected from 18 sites over an area of $770 \mathrm{Km}^{2}$ was analysed. Temperature (Temp.), pH, Total Dissolved Solids (TDS) and Electrical Conductivity (EC) were measured in the field and 15 chemical parameters analysed in the laboratory. Factor Analysis (FA) of physiochemical results indicated mineralization, weathering of silicates and $\mathrm{K}$-feldspar, and anthropogenic sources were mainly responsible for groundwater chemistry. Hierarchical Cluster Analysis (HCA) revealed sample clusters were mainly controlled by structure rather than by lithology, water source or altitude because $86 \%$ of cluster I samples occurred along a NNE-SSW trending fault zone. It was thus concluded that water-rock interaction, tectonics and anthropogenic factors are responsible for water physiochemistry.
\end{abstract}

\section{Introduction}

Assessment of ground water resources in arid and semi arid regions are of utmost importance [1]. Many developing countries are often not able to manage their water resources to sustainably meet present and future demands [2, 3]. This is because the required information is unavailable due to data gaps [4]. Thus, quantitative and qualitative hydrogeological information is needed [5].

Multivariate statistical techniques have successfully been used in several hydrogeochemical studies [e.g 6 - 10]. Apart from helping simplify and organize large data sets by giving meaningful insight, it has the added advantage of deciphering the groundwater hydrochemical facies for waters that are appearing homogeneous $[11,12]$. Understanding of geochemical processes and interaction of groundwater with aquifer may help provide information on the hydrogeology of an area which may be helpful for groundwater resources management $[3,6]$ as anthropogenic sources of contami-nation may be identified $[8,13]$. This study was carried out to provide baseline hydrogeochemical data on some communities in NW Nigeria. The main objectives are to (i) evaluate the

*Corresponding author: xc12822@126.com 
groundwater geochemistry of the area and (ii) to identify the factors that affect the chemistry of its water.

\section{Study area}

The area is located in NW Nigeria. It lies between latitude $12^{\circ} 30^{\prime} 00^{\prime \prime} \mathrm{N}$ to $12^{\circ} 45^{\prime} 00^{\prime \prime} \mathrm{N}$, and longitude $8^{\circ} 15^{\prime} 00^{\prime \prime} \mathrm{E}$ to $8^{\circ} 30^{\prime} 00^{\prime \prime} \mathrm{E}$, covering an area of about $770 \mathrm{~km}^{2}$ (Fig. 1). Climate is typical Sudan Savanna tropical climatic zone of Nigeria characterized by two distinctive seasons (dry and wet seasons). Mean annual rainfall is about $700-750 \mathrm{~mm} / \mathrm{a}$ [14]. The annual range of temperature is between 27 to $34^{\circ} \mathrm{C}$. Geologically, the study area is underlain pre-cambrian basement muscovite schist, Pan-African porphyritic granite and Plio-Pleistocene sandstone (Chad Formation) with quartzite occurring as the minor lithology. (Fig. 1)

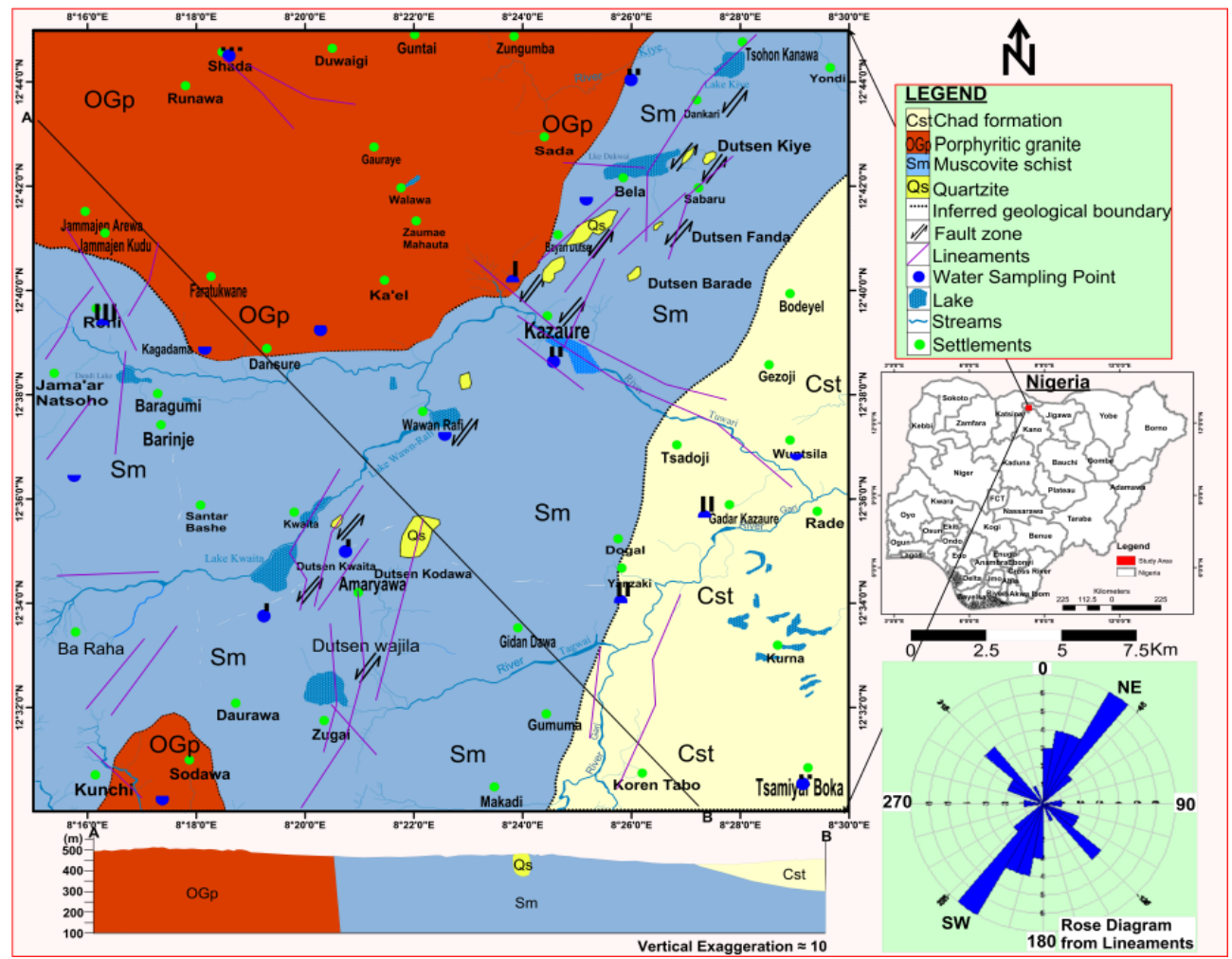

Fig. 1. Location map showing the geology of study area and location of sampling points.

\section{Materials and methods}

Eighteen water samples from ten hand-dug wells (HDW) and eight boreholes (BH) locations were collected. Physical parameters such as temperature (Temp.), electrical conductivity (EC), $\mathrm{pH}$ and total dissolved solids (TDS) were obtained with the help of fourin-one meters (Mi 806 Combined Meter Brand). Two water samples were collected from each point with one of the samples acidified (with concentrated nitric acid), labeled and transported to the laboratory. The acidified water samples were used for the analysis of cations whiles the other non-acidified water samples for the anions. The samples were 
analyzed at Multi-User Research Ahmadu Bello University, Zaria and Federal Ministry of Water Resources, Department of Water Quality Control and Sanitation, Kano using Atomic Absorption Spectrophotometric (AAS), Flame photometer and Water Kit technology based on standard procedure [15].

Descriptive and multivariate statistical analysis was carried out with Statistical Package for Social Sciences (SPSS) software. Varimax rotation was applied to principal components during Factor Analysis (FA) while applying Kaiser's criterion [16]. Hierarchical Cluster Analysis (HCA) was done using Ward's clustering procedure to obtain best results $[8,9,17]$

\section{Results and discussions}

Table 1 shows results of physiochemical analysis. HW10 and BH8 which are closely associated geographically (Fig. 1) are both responsible for the large observed variance (along with BH1). This suggests local contamination as a similar occurrence has been reported elsewhere [10].

\subsection{Factor analysis}

Factor analysis of the nineteen physiochemical components of groundwater was carried out revealing six factors which accounted for $82.73 \%$ of the total observed variance (Table 2). Factor one loadings which account for $25.76 \%$ of variability (Table 2 ) is largely related to mineralization [19] and indicates that the EC and TDS in the study area are mainly due to $\mathrm{Na}^{+}$and $\mathrm{SO}_{4}{ }^{2-}$ with $\mathrm{Ca}^{2+}$ playing a substantial role and related to the occurrences of $\mathrm{Cd}^{2+}$, $\mathrm{Cr}^{2+}$ and $\mathrm{Pb}^{2+}$. Factor two which accounts for $19.26 \%$ of observed may be associated to weathering of silicates and K-feldspar [11, 19, 20]. Gibbs plot [21] showed water-rock interaction as main influence on groundwater chemistry (Fig. 2). The third factor which accounts for $13.99 \%$ of may be related to selective weathering of rocks as mobility of $\mathrm{Cd}^{2+}$ and $\mathrm{Pb}^{2+}$ ions is increased by decrease in $\mathrm{pH}$ (acidity) [22]. Factor four explains $9.71 \%$ of the total variance and may be related to anthropogenic sources due to moderate loading of $\mathrm{NO}_{3}{ }^{-}$(Table 1). Factor five and six explain $7.06 \%$ and $6.96 \%$ of observed variance respectively. These are related to rock-water interaction (due to observed inverse relationship between $\mathrm{Zn}^{+}$sorption and temperature) [23] and anthropogenic activities respectively.

\subsection{Hierarchical cluster analysis}

Cluster analysis of samples displayed three major groups showing no preferred hydrochemical facies (Fig. 3). Typical water facies are $\mathrm{Na}+\mathrm{K}-\mathrm{SO}_{4}-\mathrm{Cl}, \mathrm{Ca}+\mathrm{Mg}, \mathrm{Na}+\mathrm{K}-\mathrm{SO}_{4}$, $\mathrm{Na}+\mathrm{K}-\mathrm{SO}_{4}-\mathrm{Cl}, \mathrm{Na}+\mathrm{K}-\mathrm{HCO}_{3}$ and $\mathrm{Ca}+\mathrm{Mg}, \mathrm{Na}+\mathrm{K}-\mathrm{SO}_{4}$ facies. The only $\mathrm{Ca}+\mathrm{Mg}-\mathrm{HCO}_{3}-$ $\mathrm{SO}_{4}$ facies occurrence in the study also was in this Cluster III. The BH1 outlier having the highest concentration of $\mathrm{HCO}_{3}, \mathrm{Cl}^{-}$and $\mathrm{K}^{+}$was a Na+K$-\mathrm{HCO}_{3}$ water-type. Group I occurred along the axis of a NE-SW trending fault zone observed in the field and documented previously (Fig. 4) [24].

Fault zones are generally known to principally affect groundwater flow paths in crystalline terrains [e.g 25, 26] and fault zone rocks in basement metamorphic terrains are often associated with spring systems [27]. HCA has been successfully used to highlight interesting water chemistry that resulted from faulting [28]. Group I is thus thought to be associated with the fault system. 


\section{Conclusions}

FA led to conclusion that mineralization, weathering of silicates and K-feldspar, and anthropogenic sources were respectively responsible for groundwater chemistry. The physiochemical evaluation of groundwater showed evidence of local contamination as two of the three samples responsible for variation of data were constrained to the WNW part of the study area while the third site of local contamination was highlighted by HCA. Structural control on groundwater chemistry was revealed by HCA as the fault zone in the area was found be closely related to cluster I. It can thus be seen that water-rock interaction, tectonics and anthropogenic factors affected the studied groundwater

Table 1. Summary of Physiochemical Results and Factor Analysis Varimax Rotation. pH (units), E. C. $(\mu \mathrm{S} / \mathrm{cm})$, Temp. $\left({ }^{\circ} \mathrm{C}\right)$ while anions, cations and metals $(\mathrm{mg} / \mathrm{l})$.

\begin{tabular}{|c|c|c|c|c|c|c|c|c|c|c|c|}
\hline \multirow{2}{*}{$\begin{array}{l}\text { Para- } \\
\text { meter }\end{array}$} & \multirow[t]{2}{*}{ Max } & \multirow[t]{2}{*}{ Min. } & \multirow[t]{2}{*}{ Mean } & \multirow{2}{*}{$\begin{array}{l}\text { Stan- } \\
\text { dard } \\
\text { Dev. }\end{array}$} & \multirow{2}{*}{$\begin{array}{l}\text { Stan- } \\
\text { dard } \\
{[18]}\end{array}$} & \multicolumn{6}{|c|}{ Principal Factors of groundwater variability } \\
\hline & & & & & & $\mathbf{1}$ & 2 & 3 & 4 & 5 & 6 \\
\hline $\mathrm{pH}$ & 6.59 & 4.74 & 5.55 & 0.44 & $6.5-8.5$ & 0.381 & -0.002 & -0.815 & -0.261 & 0.120 & 0.114 \\
\hline TDS & 530 & 20 & 133 & 124 & 1000 & 0.822 & 0.383 & -0.315 & 0.012 & -0.102 & -0.141 \\
\hline Temp. & 33.9 & 28.8 & 30 & 1.21 & - & -0.189 & 0.166 & 0.215 & 0.580 & -0.695 & -0.027 \\
\hline E.C. & 910 & 50 & 230 & 201 & - & 0.836 & 0.341 & -0.272 & -0.031 & -0.082 & 0.099 \\
\hline $\mathrm{Na}^{+}$ & 223 & 0 & 40.7 & 54 & 200 & 0.797 & -0.019 & 0.037 & 0.147 & -0.273 & -0.374 \\
\hline $\mathrm{K}^{+}$ & 165 & 5 & 30.1 & 39.2 & - & -0.048 & 0.861 & 0.326 & -0.066 & \begin{tabular}{|l|}
-0.028 \\
\end{tabular} & -0.127 \\
\hline $\mathrm{Ca}^{2+}$ & 27 & 4 & 7.56 & 5.25 & 100 & \begin{tabular}{|l|}
0.685 \\
\end{tabular} & -0.346 & 0.299 & 0.335 & -0.057 & -0.161 \\
\hline $\mathrm{Mg}^{2+}$ & 14.7 & 0 & 3.68 & 3.59 & 50 & -0.039 & -0.292 & 0.553 & -0.214 & 0.214 & 0.544 \\
\hline $\mathrm{Fe}^{2+}$ & 4.13 & 0.02 & 1.1 & 0.91 & 0.3 & -0.125 & -0.150 & 0.339 & 0.185 & 0.066 & -0.184 \\
\hline $\mathrm{Mn}^{2+}$ & 0.807 & 0.018 & 0.24 & 0.27 & 0.1 & -0.011 & 0.666 & 0.306 & -0.045 & 0.340 & -0.005 \\
\hline $\mathrm{Zn}^{2+}$ & 0.947 & 0 & 0.13 & 0.26 & 0.1 & -0.036 & 0.308 & 0.016 & 0.634 & 0.563 & -0.265 \\
\hline $\mathrm{Cr}^{2+}$ & 0.422 & 0 & 0.17 & 0.17 & 0.05 & 0.629 & -0.555 & 0.157 & -0.128 & 0.083 & 0.050 \\
\hline $\mathrm{Cd}^{2+}$ & 0.019 & 0.012 & 0.02 & 0 & 0.003 & 0.720 & 0.038 & 0.543 & 0.037 & -0.124 & 0.273 \\
\hline $\mathrm{Pb}^{2+}$ & 0.128 & 0.035 & 0.08 & 0.03 & 0.01 & 0.646 & -0.142 & 0.567 & -0.332 & 0.092 & -0.045 \\
\hline $\mathrm{F}^{-}$ & 0.6 & 0.46 & 0.53 & 0.04 & 1.5 & 0.320 & -0.738 & 0.258 & 0.102 & 0.249 & -0.299 \\
\hline $\mathrm{Cl}^{-}$ & 85.2 & 28.4 & 51.3 & 16.2 & 250 & 0.275 & 0.781 & 0.196 & \begin{tabular}{|l|}
0.039 \\
\end{tabular} & 0.293 & -0.138 \\
\hline $\mathrm{HCO}_{3}{ }^{-}$ & 345 & 24.4 & 104 & 73 & $500-1$ & -0.132 & 0.537 & 0.472 & \begin{tabular}{|c|}
-0.530 \\
\end{tabular} & -0.280 & -0.066 \\
\hline $\mathrm{NO}_{3}{ }^{-}$ & 21.4 & 10 & 14.5 & 3.26 & $50-10$ & -0.197 & 0.053 & 0.163 & 0.588 & 0.045 & 0.665 \\
\hline $\mathrm{SO}_{4}{ }^{2-}$ & 14.2 & 1.42 & 5.03 & 3.11 & 250 & 0.805 & 0.286 & -0.260 & 0.227 & 0.074 & 0.250 \\
\hline $\begin{array}{l}\text { \% Total } \\
\text { Variance }\end{array}$ & & & & & & 25.76 & 19.25 & 13.99 & 9.71 & 7.06 & 6.96 \\
\hline
\end{tabular}



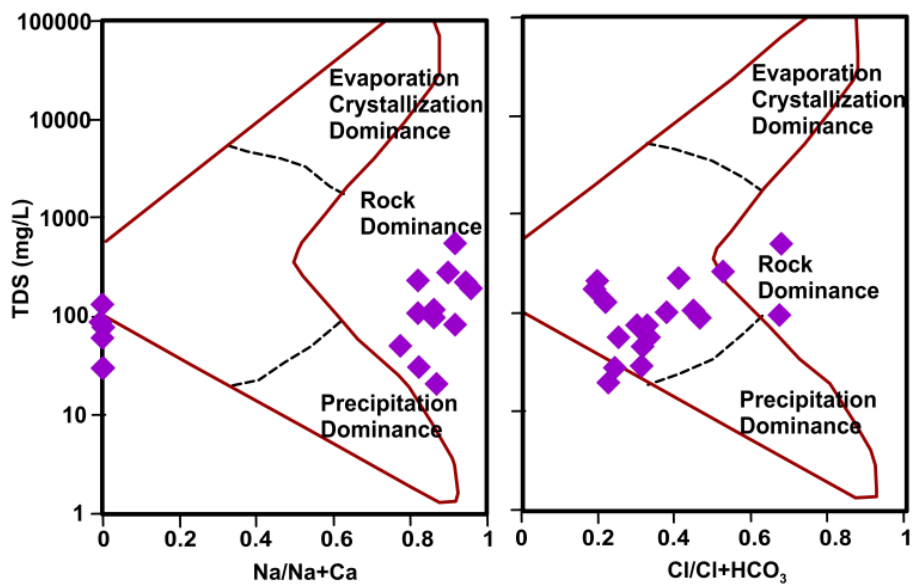

Fig. 2. Gibbs Plot indicating Water-Rock Interaction as Major Process Regulating Groundwater Chemistry.

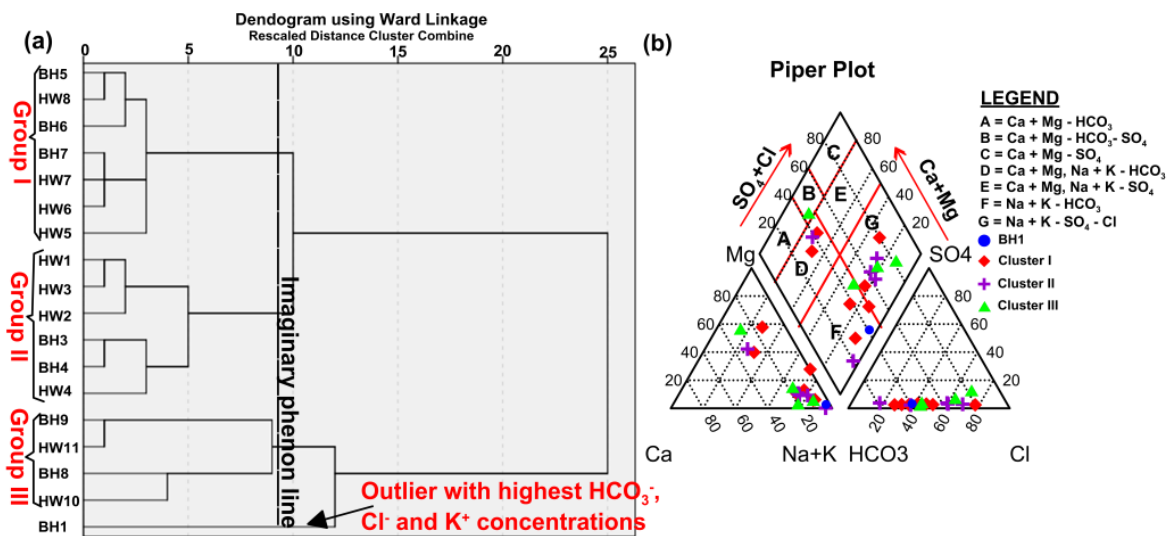

Fig. 3. (a) Dendogram Showing Major Clustering Groups; (b) Piper Plot Showing Water Facies of Clusters.

\section{References}

1. I. Hassen, F. Hamzaoul-Azaza, R. Bouhlila. Environ Monit. Assess. 188, 135 (2016)

2. WHO/UNICEF 2008 (World Health Organization and United Nations Children's Fund) (2008)

3. B.T. Kamtcheng, W.F. Fantong, M.J. Wirmvem, et al., Environ Monit. Assess. 188, 524 (2016)

4. B.L. Morris, A.R.L. Lawrence, P.J.C. Chilton, et al., Early Warn and Assess. Rep. Series, RS. 03-3. (2003)

5. Nigerian Hydrological Services Agency (NIHSA) Hydrological Mapping project. (2012). Retrieved from: http://www.nihydro.gov.ng/hydrogeological-mapping-ofnigeria/

6. W. Furi, M. Razack, T.A. Abiye, S. Kebede, D. Legesse. Hydrog. J. 20, 385-400 (2011)

7. J.E. Cortes, L.F. Munoz, C.A. Gonzalez, et al., J. Of Hydrol. 539, 113-124 (2016) 
8. J.Demirel, C. Guler. Env. Geol. 49, 477-487 (2005)

9. L.Belkhiri, L. Mouni, A. Tiri. Env. Geochem. Health 34, 1-13

10. M. Suvedha, B. Gurugnanam, M. Suganya, S. Vasudeva. J. of Geol. Soc. Of India, 74, 573-578 (2009)

11. A.N. Amadi, J. Yisa, N.O. Okoye, I.A. Okunlola. Sci. Focus, 15 (2), 326-337 (2010)

12. E. O’Shea, J. Jankowski. Hydrol. Processes, 20, pp 4317-4333 (2006).

13. D. Love, D. Hallbauer, A. Amos, R. Hranova. Phy and Chem. of Earth29, 1135-1143 (2004)

14. K. Schoeneich, M.L. Garba. Hydrog. Lec Notes, (Dept. of Geol., ABU Zaria, Nigeria, (2010)

15. APHA (American Public Health Association), 22nd ed. ,(Washington, DC: 2012)

16. H.F. Kaiser, Psychometrika, 23,187-200.

17. S. Sharma, (NY: Wiley. 1996)

18. WHO. $4^{\text {th }}$ ed. (WHO Press Switzerland, 2011)

19. X. Zhang, H. Qian, Chen, J. and Qiao, L. Water 6, 2212-2232 (2014)

20. A. Mora, J. Mahlknectht, L. Rosales-Lagarde, et al., Environ. Monit. Assess. 189, 394 (2017)

21. R.J. Gibbs. Science, 17, 1088-1090 (1970)

22. C. Appel, L. Ma. J. Environ. Qual. 31, 581-589 (2002)

23. R. Amouzi, A. Cheref, A. H. Hamzaou1. Environ. Earth Sci. 74, 4 (2015)

24. U.A. Danbatta. Global J. of Geol. Sci., 1, 1 (2003)

25. S. Leray, J.R. de Dreuzy, O. Bour, T.Labasque, L. Aquilina,.J. Hydrol. 464-465, 54-68 (2012)

26. T. Read, O.Bour,V.F. Bense, et al., Geophys. Res. Lett.(2013)

27. Bense, V.F., Gleeson, T., Loveless, S. E., Bour, O. Scibek, J. Ear. Sci.Rev, 127,171$192(2013)$

28. X. Li, H. Wu, H. Qian, Y. Gao. Water, 10, 338 (2018) 